\title{
1961 CALIFORNIA JUVENILE COURT LAW: EFFECTIVE UNIFORM STANDARDS FOR JUVENILE COURT PROCEDURE?
}

In 1961, California's juvenile court law was revised substantially by the state legislature. ${ }^{1}$ The revision was based largely on the recommendations of a special study commission on juvenile justice which convened in 1957 and issued its final report in $1960.2 \mathrm{~A}$ distillation of the commission's recommendations indicates that the revision was intended to achieve two primary objectives: (1) to enact minimum procedural standards limiting the informality of the juvenile court process; ${ }^{3}$ and (2) to construct the juvenile court law so that both existing and newly devised juvenile court procedures would be apphied uniformly in the various counties. ${ }^{4}$ These objectives seem consonant with a current nationwide re-evaluation of the proper role of juvenile court systems in the administration of justice. Historically dehinquent children were subject to ordinary criminal sanctions, ${ }^{5}$ but now it generally has been accepted that juveniles should be rehabilitated through individualized treatment with the state acting as parens patriae. ${ }^{6}$ Ordinarily this approach has been implemented by a special juvenile court system which proceeds informally, uninhibited by many of the procedural safeguards normally afforded the criminally accused. ${ }^{7}$ Although it has been held that this informality does not vio-

1 Cad. Wetrare \& InsT'Ns Code $\$ \S 500-914$. The old juvenile court law was repealed. Cal. Stats. 1961, ch. 1616, $\S 1$.

2 The commission was created by the governor in 1957. Cal. Stats. 1957, ch. 600, p. 1694. The two parts of the report are: Governor's SpEciar STUdy CoMNM'N on JUVENIIE JUSTICE, Report pt. I, Reconounendations for Changes in California's Juvenile Court Law (1960)


Justice, Report pt. II, A Study of the AdATINISTRation of Juventle Justrce IN CaIIfornia (1960) [hereinafter cited as COMn's REPORT pt. II].

3 See COMm's Report pt. I, at 10-13.

4 Ibid.

- Even today, some children who commit serious offenses are subject to criminal prosecution. Juvenile court legislation in many states authorizes juvenile courts having original jurisdiction over juvenile lawbreakers to waive that jurisdiction and transfer those offenders who are not amenable to rehabilitation to the criminal court for general prosecution. E.g., Inx. REv. StaT. ch. 23, § 2014 (1958). In some states, criminal courts have original jurisdiction over children who commit serious offenses. See note 14 infra.

${ }^{6}$ For an early discussion of the issues involved see generally EuTot, THE JUVENHE CouRT and tae Comaromity (1914). A modern survey is Rosenheim, Perennial Problems in the Juvenile Court, in JUSTICE FOR TaE Cand 1-22 (Rosenheim ed. 1962). See also Tappan, Juridical \& Adninistrative Approaches to Children With Problems, in JUSTrCE FOR THE CEMD 144-71 (Rosenheim ed. 1962). In setting forth the basic problems prompting its recommendations for revising the law, the commission asserted, "notwithstanding these observations, the commission is of the firm conviction that the protective and rebabilitative philosophy of the juvenile court law is sound and should remain unchanged. .. ." CoMasr's REPORT pt. I, at 12.

7 Juvenile courts generally hold their hearings in private. See State v. Cronim, $220 \mathrm{La} .233$, 56 So.2d 242 (1951); In re Mont, 175 Pa. Super. 150, 103 A.2d 460 (1954). Assistance of counsel often is discouraged. Diana, The Rights of Juvenile Delinquents: An Appraisal of Juvenile Court Procedures, 47 J. Cram. L., C. \& P.S. 561, 565 (1957); see Sherry, A Study Relating to a Juvenile's Right to Counsel and the Designation of Nondelinquent Minor as "Ward of the Juvenile Court," Cat. Law Reviston Comom'n, Reports, Recomomendations AND Srupies E-23 (Oct. 1960). Jury trial often is demied. In the Matter of Daedler, 194 Cal. 320, 228 Pac. 467 (1924). Contra, State ex rel. Shaw v. Breon, 244 Iowa 49, 55 N.W.2d 565 
late due process because the proceedings are civil rather than criminal, ${ }^{8}$ the informal procedures have promoted such flexibility within the juvenile process that children sometimes have been treated arbitrarily..$^{\circ}$ Recent observers have maintained that fairness requires the elimination of arbitrary treatment even though such treatment is intended to be rehabilitative rather than pumitive. They have urged that minimum procedural standards, such as special rules of evidence and provisions for counsel, will help limit the exercise of the juvenile court process to cases fully within the jurisdiction of the court. ${ }^{10}$ This comment analyzes some critical changes embodied in the revised California law and suggests the probable effectiveness of these changes in achieving the intended objectives.

A preliminary sketch of the California juvenile court process as a whole may make clear the general interrelation of the several component phases of the process which are discussed in more detail later in this comment. The California juvenile court process involves the combined efforts of the juvenile court, law enforcement agencies, county probation departments, and local and statewide rehabilitation facilities. The superior court of each county exercises the jurisdiction of the juvenile court. ${ }^{11}$ The juvenile process frequently begins with the apprehension of the youth by a police officer, who refers the child to the county probation department if he decides that further action is appropriate. If the child is physically presented to the probation department, ${ }^{12}$ the probation officer decides whether or not further detention is necessary. If so, then he has a limited time in which to initiate a juvenile court detention learing, which is confined to a determination whether further detention of the child is necessary. If detention is ordered, the child is

(1952). The protection against double jeopardy may not apply. In Moquin v. State, $216 \mathrm{Md}$. 524,140 A.2d 914 (1957), a sixteen year old arsonist was convicted in criminal court two months after a juvenile court adjudication for the same act. A similar result in Pcople v. Silverstein, 121 Cal. App. 2d 140, 262 P.2d 656 (1953) (fifteen months between adjudication and criminal conviction), has been reversed by statute, CAI. WeLFare \& INST'Ns CoDE $§ 606$. There may be no privilege against self incrimination. In re Mont, $175 \mathrm{~Pa}$. Super. 150, $103 \mathrm{~A} .2 \mathrm{~d}$ 460 (1954). More often, it is held that the court cannot compel the juvenile to testify, although it need not apprise the youth of his right against self incrimination. In re Dargo, 81 Cal. App. 2d 205, 183 P.2d 282 (1947); In the Matter of Tabbel, 46 Cal. App. 755, 189 Pac. 804 (1920); People v. Lewis, 260 N.Y. 171, 183 N.E. 353 (1932).

8 A leading case is Cinque v. Boyd, 99 Conn. 70, 121 Atl. 678 (1923). The validity of Cahifornia's juvenile court law has been upheld. See In the Matter of Daedler, 194 Cal. 320, 228 Pac. 467 (1924); In the Matter of Maginnis, 162 Cal. 200, 121 Pac. 723 (1912).

9 In In re Coyle, 122 Ind. App. 217, 101 N.E.2d 192 (1951), for instance, the adjudication of delinquency rested not on evidence that the youth was within the jurisdiction of the court, but on the ground that treatment within the juvenile court process would benefit the child. The case is discussed briefly in Paulsen, Fairness to the Juvenile Offender, 41 MrNo. L. REv. 547, 555 (1957).

${ }^{10}$ See the pioneering work of Professor Paul Tappan (Tappan, Juvenne Detinquency (1949)), from which much was drawn in the more recent work by U.S. CHIIDREN's BUREAU, Dep't of Health, Education, and Welfare, Standards for Specialized Courts Dealino Wrth ChItdren (1954). Paulsen, Faimess to the Juvenile Offender, 41 Minv. L. Rev. 547 (1957), is also excellent. Criticisms of this kind have prompted changes in juvenile court procedure in states other than California. See, e.g., N.Y.C. FAMnY Cr. Acr \$\$111-1019.

11 CaL. Wetrare \& Inst'ns Code \$ 550.

12 The police officer may refer the youth to the probation department by two methods: (1) he can retain the youth in custody and take him in person to a probation officer; (2) be can release the youth from custody and issue a citation requiring the youth's appearance before a probation officer at a later time. See text following note 39 infra. 
held in juvenile hall pending an adjudicatory hearing. The probation officer also is responsible for deciding whether or not to file a petition with the juvenile court, thereby initiating adjudicatory proceedings on behalf of the youth. If a petition is filed, the juvenile court conducts an adjudicatory hearing, at which it first determines its jurisdiction. If the child is subject to juvenile court jurisdiction, the court then proceeds to a disposition of the case. Pursuant to the disposition, the child may be placed on probation, placed in a foster home, placed in a private or county canip, or committed to the California Youth Authority.

\section{I}

\section{JURISDICTION}

Jurisdiction of the juvenile court over a given child depends upon two things: $(A)$ the age of the child; and $(B)$ the conduct of the child, the conditions under which he lives, or both.

\section{A. Age}

Juvenile court jurisdiction under the 1961 revision covers all youths under twenty-one years of age. The juvenile court has exclusive jurisdiction over all minors under sixteen, original jurisdiction over minors sixteen to eighteen, and jurisdiction concurrent with criminal courts over minors eighteen to twenty-one. ${ }^{13}$ Other states sometimes deny certain minors access to the juvenile court, ${ }^{14}$ but California's inclusion of all minors would seem more consistent with the presumption that all "young people" who have run afoul of the law can be rehabilitated if properly "treated."

\section{B. Acts or Conditions Precedent to Jurisdiction}

The acts or conditions upon which jurisdiction may be based under the revised law are contained in three sections: (1) section 600 describes minors who are

13 Cat. Welfare \& Inst'ns Code $\$ \$ 600-02,604,70 \%$. The law prior to 1961 provided essentially the same age limits with one possible exception: Exclusive jurisdiction may now be broadened by establisling sixteen as the minimum age for certification for criminal proceedings. Previously, the minimum age for certification was ambiguous, and might have been fourteen. Compare Cal. Stats. 1937, ch. 369, $\$ 832$ (formerly Cat. WeLFare \& INST'Ns CodE § 832) with Cal. Stats. 1949, ch. 762, \& 1 (formerly CAL. WeLFARE \& INST'NS CoDE § 834). See COMnM's ReporT pt. II, at 23.

14 Some states provide rather low age limits. For instance, some limit jurisdiction to minors under seventeen, e.g., Mo. ANN. STAT. $\$ 211.021,211.031$ (1962), and some to minors under sixteen, e.g., N.C. GEN. STAT. \$110-21 (1960). Some states distinguish between the sexes. E.g., N.Y.C. FAMIIX Cr. Act $\$ 712$ (b) (1962), defines a person in need of supervision as "a male less than sixteen years of age and a female less than eighteen ... who is incorrigible ... and beyond the lawful control of parent ... and requires supervision or treatment." Some states provide that a youth who commits a serious offense cannot be tried in juvenile court even if he is within the normal age limits for delinquency proceedings. See, e.g., Colo. REv, StaT. ANn. \$22-8-1(3) (1954). For recent surveys of the various state laws, see LEGrsLATIVE Research Councit, Mass. Hodse of Representattves, Report ReIATIVE to aN INDEPENDENT Systear of JUVenile Courts (1962); Sussmanan, Juvenile Deunvouency 65 (rev. ed. 1959). 
dependent, neglected, or abandoned by their parents; ${ }^{15}$ (2) section 601 describes minors whose behavior manifests a tendency towards delinquency; ${ }^{10}$ and (3) section 602 describes minors who violate state, local, or federal criminal law, or who violate the terms of their probation after having once been adjudged delinquent under section $601 .^{17}$ These sections cover an extremely wide range of circumstances. ${ }^{18}$ For instance, the violation of any ordinance technically would be sufficient to invoke the jurisdiction of the court; or a child could be found to be a habitual truant subject to the jurisdiction of the court after a total of five days unexcused absence or tardiness from school. ${ }^{10}$ The broad language of the sections also may be subject to overlapping. For instance, a youth who is habitually truant from school would seem to fit section 601 but he may fit section 600 as well if

15 CAL. WELFARE \& INST'NS CODE $\$ 600$, which provides that any minor is within the jurisdiction of the court:

(a) Who is in need of proper and effective parental care or control and has no parent or guardian, or has no parent or guardian willing to exercise or capable of exercising such care or control, or has no parent or guardian actually exercising such care or control. (b) Who is destitute, or who is not provided with the necessities of life, or who is not provided with a home..., or whose lome is an unfit place for him by reason of neglect, cruelty, or depravity of ... [the] person in whose custody or care he is.

16 CAL. WeLFare \& INST'NS CODE $\S 601$, which provides that any minor is within the jurisdiction of the court

who persistently or habitually refuses to obey the reasonable and proper orders or directions of his parents, guardian, custodian or school authorities, or who is beyond the control of such person, or ... who is a habitual truant ... or who from any cause is in danger of leading an idle, dissolute, lewd, or immoral life. . . .

17 CAL. WELFARE \& INST'NS CODE $\S 602$, which provides that any minor is within the jurisdiction of the juvenile court "who violates any law ... or any ordinance ... defining crime or who, after having been found by the juvenile court to be a person described by Section 601, fails to obey any lawful order of the juvenile court. ..."

18 Essentially the same acts and conditions provided the basis for jurisdiction prior to the revision. Former $\S 700$ contained fourteen subsections. New $\S 600$ is essentially a grouping of subsections (b) through (e) of $\S 700$. New $\S 601$ groups subsections (i) through (k) of $\S 700$. New $\$ 602$ is subsection $(m)$ of $\$ 700$, revised to include federal crimes and violations of court orders. See Covar'x Report pt. I, at 63 (proposed Cal. Welfare \& Inst'ns Code $\S \S 600-02$ ). Subsections (a) and (f) through (h) of former $\$ 700$ covered cbildren who were found begging, vagrant or involved in criminal associations, labitually using drugs or intoxicating liquors, or visiting bars and poolrooms. These provisions were specifically excluded in the regrouping apparently because they were rarely used under the old law. See Comm'N REPORT pt. II, at 7. It would seem that children found under such circumstances might either be breaking a law or ordinance, or be leading idle, dissolute lives within the meaning of $\$ \S 601$ or 602 .

10 CaI. Welfare \& INST'Ns CoDe $\$ 601$ covers habitual truants "within the meaning of any law of this state. ..." Five days' absence from school constitutes habitual tardiness under CAL. Educ. Code $\$ \S 12404-05$.

It has been said that a majority of California's adolescents could have been declared wards at any given point in time under the broad descriptions of the old law. See Comm's REPORT pt. II, at 6 . The analysis of one juvenile court judge is that the new provisions provide a broad definition of the court's power to hear and determine a case where such breadth more properly should appear in the court's discretionary exercise of that power. Breitenbach, Due Process of Law for Juveniles Revisited, 37 Cax. S.B.J. 32 (1962). Under similar statutes in other jurisdictions, appellate courts have at times insisted that a course of conduct rather than a single act be proved to establish delinquency. See, e.g., Kahm v. People, 83 Colo. 300, 264 Pac. 718 (1928) ; State ex rel. Shaw v. Breon, 244 Iowa 49, 55 N.W.2d 565 (1952); Jones v. Commonwealth, 185 Va. 335, 38 S.E.2d 444 (1946). 
circumstances indicate that he is being neglected by his parents. ${ }^{20}$ These broad jurisdictional bases may be proper to ensure that the court has power to act in cases of children whose lives obviously are deteriorating, ${ }^{21}$ but the broad coverage and possible overlapping of jurisdictional provisions suggest that the action taken with respect to a given set of facts may vary from county to county.

It becomes relevant to consider whether juvenile court procedural safeguards can operate effectively with such broad jurisdictional provisions. The present statutes impose some limitations on the juvemile court dispositions applicable to juveniles within given jurisdictional categories. For example, commitment to the California Youth Authority is authorized for section 602 wards and in some cases for section 601 wards, ${ }^{22}$ but is not authorized for section 600 dependent children. ${ }^{23}$ Dependent or neglected children must be treated and detained in separate facilities, ${ }^{24}$ and dependent children's dispositions are subject to annual review. ${ }^{25}$ To the extent that the continued existence of broad jurisdictional definitions creates uncertainty as to which section will be applied in a particular county to a given set of facts, it is doubtful that there will be uniform application of the legislative provisions for "special treatment."

20 The rather high incidence of overlapping between CAL. WeLFARE \& INST'Ns CODE $\$ \S 600$ and 601 was observed by one supervisory probation officer:

In too many cases we have girls being declared delinquent when the homes from which they come are unfit [declarations of dependency therefore being more appropriatel. . . . In a recent case, a girl declared to be beyond the control of her parents remained in Juvenile Hall until we could get her into Napa State Hospital. She is a severely brain damaged child but Napa has discharged her on the grounds that she is not legally mentally ill but is in need of a protective environment. . . . The inother deserted this girl and the father is an alcoholic. This girl is presently in Juvenile Hall. ... In another case, a girl was declared a ward of the court when she gave birth to a baby and named her brother as the child's father. The history of this family is one of incest among all members of the family and our girl, who was declared a ward of the court, had been the victim of incest by her father from the time she was a very sinall child, later was forcibly raped by her brother-in-law in whose home she sought refuge against the repeated continued sexual molestation by her father. ...

Confidential Intra-Agency Meunorandum Made Available to the Authors, 1962.

21 See Paulson, Fairness to the Juvenile Offender, 41 MrNo. L. Rev. 547, 557 (1957).

22 Commitment to the Youth Authority of wards adjudicated under CaL. WeLfare \& INST'NS CODE $\$ 601$ mnst be preceded by a noticed hearing upon a supplemental petition. The supplemental petition inust contain a concise statement of facts showing that the previous disposition has not been effective in the rehabilitation of the minor. CAL. WELFARE \& INST'NS CODE $\$ \S 730,777$.

23 CaL. Welfare \& Inst'ns CODE $\$ \$ 727,730-31$.

24 CaL. Wetrare \& Inst'ns Code $\$ 506$.

25 Cat. WeJfare \& Inst'Ns Code \$ 729.

20 One reason the commission recommended that dependent children be distinguished from juveniles manifesting delinquent tendencies was to prevent the labeling of dependent children as delinquents. See CoMar'N REPorT pt. I, at 19-20. Although not recominended by the coinmission, the legislature emphasized the distimctions created by the separate groupings by terming as "dependent child" a youth adjudicated under CAI. WELFARE \& INST'NS CODE § 600; youths adjudicated under CAT. WELFARE \& INST'NS CODE $\$ \S 601$ and 602 are wards of the court. Compare CAL. Welfare \& Inst'Ns CODE $\$ 725$ with CoMar'N RERORT pt. I, at 76 (proposed Cal. Welfare \& Inst'ns Code $\$ 725(\mathrm{~b})$ ). In view of the broad jurisdictional provisions of California law, it is possible that the label placed upon a given child inay not reflect accurately the circumstances giving rise to his adjudication. On the labeling issue see generally Paulsen, The Delinquency, Neglect, and Dependency Jurisdiction of the Juvenile Court, in JUSTICE FOR THE CHITD 44 (Rosenheim ed. 1962). 
II

\section{PREADJUDICATTON}

\section{A. Role of Peace Officer}

A youth's experience in the juvenile court process frequently begins with his apprehension by a police officer. ${ }^{27}$ Section 625 of the Welfare and Institutions Code provides in part: "A peace officer may, without a warrant, take into temporary custody a minor: (a) Who is under the age of 18 years when such officer has reasonable cause for believing that such minor is a person described in sections 600,601 , or $602 \ldots .28$

Since section 602 is sufficiently broad to include misdemeanors committed without the presence of the appreliending officer, ${ }^{29}$ section 625 clearly authorizes apprehension without a warrant in such cases. ${ }^{30}$ Legalizing such apprehensions without a warrant was intended to inject uniformity into arrest procedure and to eliminate certain apprehension practices found detrimental to proper juvenile court administration. For instance, police frequently disregarded warrant requirements and arrested juveniles on facile grounds, such as absence of parental control or danger of leading an idle or dissolute life. ${ }^{31} \mathrm{~A}$ few large police departments and nearly one-half of the smaller departments protected themselves adequately in such situations by obtaining warrants from lower criminal courts; ${ }^{32}$ but the use of a warrant often resulted in automatic certifications of cases from the lower court to the juvenile court and circumvented the screening processes of the prom bation officials. ${ }^{33}$

The fact that section 625 applies only to minors under eighteen years of age suggests that police still may be persuaded to obtain warrants when dealing with youngsters aged eighteen to twenty-one. For example, section 625 may not be applied by some police officers in cases where age is in doubt. ${ }^{34}$ If an officer reasonably believed that a group of youngsters-some under eighteen and some over

27 COMac'N REPORT pt. II, at 35. Other sources of referral are schools, county welfare departments, and-particularly where the youths are girls-parents or relatives. Ibid.

28 The term "peace officer" includes others than police officers. For instance, probation officers are considered to be peace officers. CaL. Wetrare \& INST'Ns Code § 584. Since police are more likely to be concerned with apprehension than other peace officers, however, the police role is emphasized in this discussion.

29 See note 17 supra.

30 The former statute was silent on this point. See Cal. Stats. 1949, ch. 736, $\$ 1$ (formerly Cax. Welfare \& Inst'Ns Code \& 729). Apparently CaL. Pen. Code \& 836, which does not authorize such procedure, governed juvenile arrests. See CoMM'N REPORT pt. II, at 96.

31 Both grounds were sufficient to support adjudication for delinquent tendencies. See Cal. Stats. 1937, ch. 369, \& 700 (b), (k) (formerly Cat. Wetfare \& INST'NS Code $\& 700$ (b), (k)); CONCMI'N REPORT pt. II, at 96.

32 CoMrar's Report pt. II, at 96.

33 When a person under the age of eighteen years is brought before a criminal court, that court must suspend its proceedings and certify the case to the juvenile court. Upon receipt of the certification, the juvenile court must immediately notify the probation officer who is required to file a petition in the case. CAI. WELFARE \& INST'NS CODE 8 604(d). The commission's proposal to channel lower court certifications through the probation departments' screening machinery by making the certification an "application" for a petition was rejected. See Comas's ReporT pt. I, at 64 (proposed Cal..Welfare \& Inst'ns Code \$ 604).

34 Youthful appearing eightecn year old boys may not carry draft cards and may not possess a driver's license or other identification. Lack of such identification seems even more likely among eighteen year old girls. 
eighteen-had committed misdemeanors out of his presence, he could either apprehend in piecemeal fashion or postpone any action until he obtained a warrant for the older youths. If he chose the latter alternative, the officer might procure warrants for the younger youths as well. In addition, an officer arresting an individual youth might wish to secure a warrant in a marginal case; arrest without a warrant probably is not within the law if the individual is over eighteen even though the officer reasonably beheved that he was under eighteen. These difficulties might be remedied by amending the statute so that it would expressly authorize apprehension without a warrant upon the reasonable belief that the juvenile is under eighteen. The statute then would validate the apprehension of some youths actually older than eighteen. Since such apprehensions might be invalid in criminal court, ${ }^{35}$ the amendment should provide that the juvenile court has exclusive jurisdiction of the juveniles thus apprehended. ${ }^{36}$

Police may be persuaded to secure warrants to avoid a possible limitation on the use of evidence obtained pursuant to the revised apprehension procedure. For example, if the apprehension of a seventeen-year-old youth is based on a misdemeanor committed without the presence of the officer and a subsequent search reveals marihuana on the youth's person, the law would seem to permit certification by the juvenile court to the criminal court for prosecution on a felony charge. ${ }^{37}$ Since the new procedure does not meet criminal law standards with regard to apprehension for misdemeanors not in the presence of an officer, it is doubtful that the evidence of narcotics gathered pursuant to the arrest could be used in criminal court. ${ }^{38}$

Prior to 1961, the broad discretion left to police in apprehending juveniles, together with a propensity of the pohice to detain the youths that they apprehended, contributed substantially to California's excessive detention rate. ${ }^{39}$ The revised law seeks to reduce the detention rate by delineating a rigid postapprehension procedure. The apprehending officer must either (1) release the minor, (2) cite him to the probation department and release him immediately on his or

35 See note 38 infra.

30 The encroachment on the concurrent jurisdiction of the criminal courts in such cases would seem slight, since the amendment would apply only to youths eighteen or older whose ages are in doubt and who commit misdemeanors out of the presence of the appreliending officer. Extending the age limit to twenty-one years as an alternative solution would seem unwise. By authorizing arrests without a warrant even where the officer knows the youth to be eighteen or older, such a provision would create a double standard for misdemeanor arrests of eighteen to twenty-one year olds which could be troublesome in view of the concurrent jurisdiction of juvenile and criminal courts over youngsters of these ages. See CoMMr'N REPORT pt. II, at 106 , indicating that in practice most eighteen to twenty-one year olds initially are referred to criminal courts.

37 Possession of marihuana, unless within a narrow area of privilege, is a felony. CAL. Heazth \& Safety Code \$11530. See CaL. Welfare \& Inst'ns COde \& 707 authorizing certification from juvenile to criminal court in some cases involving felonies. See also People v. Evans, 175 Cal. App. 2d 274, 345 P.2d 947 (1959).

38 Under criminal law, a warrant is required for arrest for misdemeanors not conmitted in the presence of the arresting officer. CaI. PEN. Code $\S 836$; People v. Garrison, $189 \mathrm{Cal}$. App. 2d 549, 556-57, 11 Cal. Rptr. 398, 403 (1961). Marihuana obtained incident to such an arrest without a warrant probably would be deemed to be evidence obtained pursuant to an illegal arrest and would have to be excluded from evidence. Mapp v. Ohio, 367 U.S. 643 (1961). For a discussion of the potential impact of $M a p p$ on California rules, see Collings, Toward Workable Rules of Search and Seizure-An Amicus Curiae Brief, 50 CALIF. L. REv. 421 (1962); Pcople v. Mickelson, 59 A.C. 465, 380 P.2d 658, 30 Cal. Rptr. 18 (1963).

39 See COMMr's REPORT pt. II, at 103-04. 
his parent's promise to appear before the probation officer, or (3) deliver him "without unnecessary delay" to the custody of the probation officer. ${ }^{40}$ The arresting officer must select the alternative that least restricts the minor's freedom of movement, provided that the alternative is compatible with the best interests of the minor and the community.11 Since the police officer must either release an apprehended youth or refer him to a probation officer, the statute seems to extend to the probation officer the ultimate authority to detain or release the youth. ${ }^{42}$ The statute probably eliminates the pre-1961 practices of those law enforcement agencies that detained and released youths without consulting the probation department, ${ }^{43}$ and probably reduces detention rates to the extent that these practices caused unnecessary detention. ${ }^{44}$ However, the scope of the officer's alternative duty to "release" the youth is unclear. ${ }^{45}$ The provision for "release" may be read in two ways: (1) to permit the police to investigate and interrogate the minor at the police station, or detain the minor there while disposing of other matters, ${ }^{46}$ or (2) to require an immediate release following an estimate of the situation by the patrolman on the beat. A reading of the statute to permit at least limited interrogation at the police station is made credible by the fact that the commission's recommended qualification of "release without unnecessary delay"

40 CAT. WELFARE \& INST'NS CODE $\$ 626$. Under the citation system, the police officer releases the youth. However, he gives the youth written notice to appear before the probation officer at a future date. A duplicate copy of the notice is filed with the probation officer. As a condition to release, the police may require the youth or his parent to sign a written promise that either or both will appear at the time and place designated in the notice. See CAL. WELFARE \& INST'NS CODE $\$ 626(\mathrm{~b})$.

41 Cat. WetFare \& INST'NS CODE \$ 626. Where impressionable youths are involved, it seems especially important that these procedures be observed because of the possibility that wrongful police contacts may effect recidivist behavior. The potential influence of police contact with juveniles is well illustrated by a recent study of Youth Bureau officers in Detroit. Effectiveness was measured by comparing officers serving in the same precincts as to the percentage of nonrepeaters among boys for whom they were the first police contact. Highly significant differences were found among the officers for which the only account was the way in which the minors were handled. Wattenberg \& Bufe, The Effectiveness of Police Youth Burecu Officers, J. CRrax. L., C. \& P.S. (1963) (to be published).

${ }^{42}$ This authority seems consistent with the responsibility of the probation officer to manage and control the juvenile hall. See Cat. WexaAre \& Inst'ss Code \& 852.

${ }^{43}$ A 1958 opinion of the attorney general declared the intent of the law at that time to vest the ultimate authority to detain in the probation officer. 32 Ops. Cax. Art'Y GEN. 61 (1958). Nevertheless, some law enforcemeut agencies detained youths in juvenile hall and police lockups without co-ordinating with the probation department. Comm'v REPORT pt. II, at 104-05.

44 Where, however, the juvenile is taken into custody after the probation office has closed for the day, the California attorney general beheves that there would be sufficient compliance with CAT. WELFARE \& INST'NS CODE $\$ 626$ to deliver the ininor to the probation officer at 8 a.m. the following day. 39 Ops. CAx. ATT'Y GEN. 269 (1962). Where the youth was apprehended on the eve of a three day holiday week end, the period of detention could be considerable. Perhaps in contemplation of this problem, the Alameda County Probation Department has increased its staff and extended office hours to include evenings and week euds. See Barrett, Police Practices and the Law-From Arrest to Release or Charge, 50 CAIrr. L. REv. 11, 51-52 n.120 (1962).

45 Regarding the alternative duty to release, CAx. WeLfare \& InsT'Ns CoDE \$626(a) simply says, "He [the police officer] may release such minor ...."

46 One writer has suggested, as reasonable, a similar interpretation of CAx. PEN. CODE $\S 849$, which authorizes the police to release suspects in criminal cases. See Barrett, sutpra note 44 , at 30 . 
was omitted by the legislature. ${ }^{47}$ Such an interpretation, however, would create the anomalous possibility that the authority of police to detain and interrogate is broader in cases of release than in cases where the juvenile is delivered to the probation officer. This possibility would seem to militate against the objectives of the statute. The ambiguity might be remedied by a statutory amendment providing for either immediate release or release without unnecessary delay.

\section{B. Role of Probation Officer}

A youth may be referred to the probation officer by several means. ${ }^{48}$ In cases where the child is in the temporary custody of juvenile authorities when lie is referred, the probation officer must decide whether or not the youth should be detained pending the disposition of his case. In all cases, the probation officer must decide whether further action should be taken on tlie juvenile's behalf. Such action may be official action by the juvemile court upon the probation officer's filing a petition, or it may be an unofficial program of supervision administered by the probation department.

\section{Detention Decision}

The probation department now has the sole responsibility of deciding whether to detain an appreliended youth pending disposition of his case. ${ }^{49}$ The youth must be released immediately unless the probation officer decides that further detention is necessary, basing his decision on the following specific criteria: (1) whether further detention is a matter of immediate and urgent necessity for the protection of the youth, or of the person or property of another; (2) whether the youth is likely to flee the jurisdiction of the court; and (3) whether the youth has violated an order of the juvenile court. ${ }^{50}$ The centralization of the detention decision clearly increases the probation officer's workload to the extent that such decisions were made previously by other agencies. It is not clear that all pro-

47 Compare Car. Werfare \& INST'NS CODE $\$ 626$ with COMMm'N Report pt. I, at 65 (proposed Cal. Welfare \& Inst'ns Code $\$ 626$ ). Professor Sherry does not beheve the phrase "without unnecessary delay" permits a detention for investigation in adult cases. Sherry, The Law of Arrest, Search and Seizure, in 58 Cal. Peace Ofricer Tratning Pub. No. 1 (5th rev. 1957). If the legislature adhered to a similar interpretation in striking the phrase from $\$ 626$, it would seem that some time for investigation was intended.

48 For example, police may personally bring the youth to the probation department, or police might release the youth and make the referral by having the youth sign a citation to appear before the probation officer, or a parent or other person might apply to the probation department for a petition to be filed with juvenile court. See text preceding note 41 supra; CAX. WeLFARE \& INST'NS CODE \& 653.

40 Prior to 1961, law enforcement agencies often shared the responsibility. Concas'N REPORT pt. II, at 104-05; see note 43 supra.

50 CAI. WELFARE \& INST'NS CODE $\$ 628$. Formerly, detention was authorized simply when sucli action was "necessary for the protection of the welfare of the child." Cal. Stats. 1949,

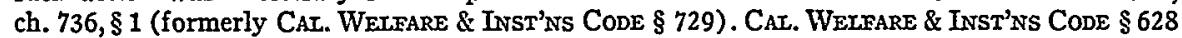
was intended to embody a "basic reorientation of juvenile detention philosophy" to the effect that "a child shall be released unless there is good reason to detain him." COMDs'N REPORT $\mathrm{pt}$. I, at 44. The legislature's authorization of detention where the youth has violated an order of the juvenile court seems inconsistent with the "reoriented" juvenile detention philosophy. If a minor is not a rnnaway risk and there is no danger to himself or to the person or property of others, it is difficult to see why he should be detained merely on the ground that he has violated an order of the court. Such detention would seem to be retributive punishment, hardly a "good reason" to detain the youth. 
bation departments have taken steps to meet the added workload, although some have, ${ }^{51}$ but even the steps that have been taken may be inadequate to meet the crush of new cases..$^{52}$ Periods of high caseload pressure may result in the probation officer's basimg his decision on criteria not authorized by the statute, such as initial impression, likelihood of referral to juvenile court, punishment, or other reasons sometimes used prior to $1961 .{ }^{53}$

There are three possible ways in which the use of proper criteria probably can be enforced. One obvious way is the effective control of probation personnel by supervisory officers. Second, some administrative control of probation department practices probably will emanate from the juvenile court. ${ }^{54}$ Juvenile court judges may guide probation policy by exercising their power to appoint and remove probation officers, but this may prove to be of little value in individual instances of detention based upon improper criteria. Consequently, the third check on the detention decision, the detention hearing in juvenile court, is perhaps the most important. The effectiveness of this learing in preventing unjustified detention is discussed below. ${ }^{5 \overline{5}}$

\section{Decision to Take Further Action}

The revised law substantially increases the number of cases in which probation departments must use their investigative facilities to determine whether a petition should be filed to initiate official action. For example, probation departments now bear sole responsibility for deciding if a petition should be filed.50 Hence, the probation department has inherited the cases where, previously, police

51 See note 44 supra.

52 Even under the old law, probation officers were pressed for time by the large number of cases before them. Probation officers in fifteen of the twenty largest counties averaged from one to four hours per case. CoMON's REPoRT pt. II, at 39.

53 See COMOM'N REPORT pt. II, at 81, indicating that detention was frequently used as a punishment device prior to 1961. Such punishment was usually characterized as "shock treatment." Detention at the discretion of the probation officer not only would seem to have questionable efficacy as a means for treatment but would seem clearly to violate due process by depriving a youth of his freedom prior to an adjudication of his case. This practice should be distinguished from the practice of some judges who impose postadjudication detention designed to treat by punishing. Postadjudication detention probably departs from the spirit, though perhaps not the letter, of the statute. See CaL. WeLFare \& INST'Ns Code \$\$ 726(c), 730. Such detention may also violate a youtli's constitutional rights if the juvenile court process does not afford all the procedural protections required in criminal proceedings. See $I n$ re Contrcras, 109 Cal. App. 2d 787, 241 P.2d 631 (1952).

$\tilde{5}^{4}$ Prior to 1961 , the juvenile court exercised some control over probation department policy by virtue of the judge's power to appoint and remove prohation officers. Two exceptions were Los Angeles and San Diego counties, which have county charters that vest administrative control in the county board of supervisors. CoMm's REPORT pt. I, at 39-40; see Cal. Stats. 1937, ch. 369, $\$ \S 630-32,635,637$ (formerly CaL. Wedfare \& INST'Ns Cone $\$ \S 630-$ $32,635,637)$. The legislature apparently rejected the commission's proposal that, in all countics, such administrative controls be vested in the county board of supervisors instead of the juve-

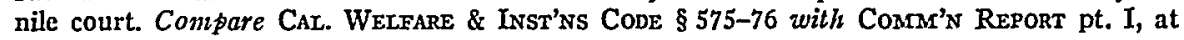
60-61 (proposed Cal. Welfare \& Inst'ns Code \$\$ 575-76).

55 See discussion in part III, B, 1, following note 121 infra.

50 Before 1961, police officers could make the background investigation and file the petition with the juvemile court, such filing subject only to the approval of the probation officer. See Cal. Stats. 1937, ch. 369, \& 721, as amended (formerly CaL. Welfare \& INST'Ns CodE \& 721). The police still retain a limited power to screen by virtue of their alternative to release embodied in CAL. WeIfaRe \& INST'NS CODE $\$ 626$. 
officers would not have released the youth but would have filed their own petitions. ${ }^{57}$ In addition, cases formerly channeled through lower courts now will be handled by probation officers to the extent that the revised apprehension procedure effectively permits arrest without a warrant. Since additional demands are imposed on the time of probation personnel, it would seem imperative that the law emphasize the proper grounds for filing a petition in order to curtail slipshod decisions. For example, it would seem fundamental that a decision to file a petition begin with a determination that sufficient evidence exists to show that the youth falls within juvenile court jurisdiction. Yet many probation officers apparently failed to consider the existence or nonexistence of such evidence under the old law. ${ }^{58}$

Where, after investigation, the probation officer concludes that a youngster either is or soon probably will be within the jurisdiction of juvenile court, he may undertake a program of supervision of the youth in lieu of filmg a petition. This "informal probation" must be with the consent of the parent and must not exceed a period of six months. ${ }^{59}$ Due process would seem to require that informal probation be based either upon the existence of juvenile court jurisdiction over the youth or upon the youth's voluntary submission to supervision. ${ }^{60}$ Since informal

57 CAI. WELFARE \& INST'NS CODE $\$ 626$ indicates that the citation system, whereby the police may refer a youth to the probation department by written citation, must be employed by the police officer unless he makes the referral by physical presentation to the probation department. See text preceding note 43 stipra. The citation system would seem to contribute substantially to the probation department's total workload, since, prior to 1961 , police agencies often conducted their own investigations of certain cases, calling upon the probation officer only for approval of the application for petition submitted by the police. See Collins, Califorria's New Juvenile Court Law, Cal. Peace Officer, Nov.-Dec. 1962, pp. 5, 47. According to one probation department that employed the citation system prior to 1961, the system is intended for use only with "juveniles involved in offenses of a minor nature or those in trouble for the first time." Interviews With Officers of Alameda County Probation Dep't, 1962. The statute does not limit the citation system to such minors. CaL. WeLfare \& INST'NS CODE $\S 626(\mathrm{~b})$.

The power of the police officer to share in the probation screening process has been curtailed further by CAI. WELFARE \& INST'NS CODE $\$ \S 654-55$. These sections provide that, where the probation officer decides to place a youth on informal probation rather than to file a petition, the apphicant for a petition-generally a police officer-cannot appeal this decision to the juvenile court judge.

58 COMaM's REPORT pt. II, at 37. A check on filing petitions where such filing is not justified by the sections defining the jurisdiction of the court is, of course, provided by the adjudicatory hearmg. The effectiveness of that hearing in insuring that jurisdiction is justifiably invoked is discussed later in this comment. See text accompanying note 129 infra.

50 Cal. Wetrare \& Inst'ns CODE $\$ 654$. Informal probation is justified on the theory that a child will suffer harm merely from being adjudicated a delinquent and, because of the inclusive definitions of delinquency, that it would be unjust to label "delinquent" a child who has not really committed an act harmful to the community. See Tappan, Unofficial Delinquency, 29 NEB. L. REv. 547 (1950).

60 U.S. Chmoren's Buread, Def't of Healtr, Education, amo Welfare, Standards for Spectalized Courts Dealnng WitH CHIIDREN 45 (1954); see Diana, The Rights of Juvvenile Delinquents: An Appraisal of Juvenile Court Proceedings, 47 J. Crrar. L., C. \& P.S. 561, 564 (1957); Nattonat Probatton \& Parole Ass'N, Standard Juventex Court Act § 12 (6th ed. 1959). This requirement would seem doubly important because in over ninety per cent of the fifty-three counties studied by the Governor's commission, supervision of juveniles on informal probation was either less comprehensive or no different from supervision in adjudicated cases. COMM'N REPORT pt. II, at 47, table 57 . Under the new law, the possibility also arises that a youth may be subject to criminal prosecution even after having served a six month period of informal probation. CAL. WELFARE \& INST'NS CODE $\$ 606$ prohibits double jeopardy 
probation is authorized in cases where the court does not yet have jurisdiction, it becomes essential that subjection to informal probation be made "voluntary" by the statute. ${ }^{61}$ Nevertheless, two omissions from present law suggest that "voluntariness" has not fully been made a requirement. First, although the statute specifically requires the consent of a parent or guardian, it does not require the consent of the youth. A youth's opportunity to answer for himself would seem advisable, apart from the desirability of his co-operation, to the extent that conflicts of interest arise between parent and child. ${ }^{62}$ Second, it appears that the parent may not withdraw consent, once given, during the six month period of mformal probation. It might be argued that the provision for "consent" implies a right to revoke that consent, but a contrary implication flows from the fact that the former law expressly authorized parental revocation of consent while the present law does not. ${ }^{63}$ To the extent that informal probation is not voluntary, the revised law would seem to authorize a questionable combination of extralegal action and obligatory treatment.

\section{III}

\section{ADJUDICATION}

\section{A. Court Personnel}

\section{The Judge}

The presiding judge of the superior court is authorized to designate one or more of his brethren to serve for a year as a juvenile court judge. ${ }^{.4}$ In practice, however, there are various methods of selection that deviate from the literal directions of the statute. The position is rotated systematically among the superior court judges ${ }^{65}$ or based upon personal request, recommendation of a committee of judges, or mutual agreement of the judges. ${ }^{66}$ Reluctance of judges to serve on

only in cases where a petition has been filed. This possibility increases the urgency that informal probation be voluntary, not by mandate of the probation department. Prior to 1961, only $55 \%$ of the counties secured parental consent to informal probation-even though former $\$ \S 638$ and 721 required such consent. CoMas's REPORT pt. II, at 47; see Cal. Stats. 1937, ch. 369 , § 638, as amended; Cal. Stats. 1937, ch. 369, § 721, as amended.

01 Whether informal probation ever can be truly voluntary is a question that merely can be raised by this comment. The alternative of full-scale juvenile court hearings may persuade many juveniles or their parents to consent to informal probation whenever that course is offered to them. Since the probation officer retains the power to file a petition for an adjudicatory hearing throughout the period of informal probation, fear of the consequences of juvenile court action may prevent revocation of consent by the minor or parent. See CaI. WELFARE \& INST'NS CODE § 654.

02 For example, behieving that treatment would do his child some good, the parent may urge that the probation department undertake supervision of the child without regard for the propriety of treatment under the juvenile court law. The revised law expressly recognizes that such conflicts may exist by providing that, in hearing such cases, the court may appoint separate counsel for the youth. See CaL. WeIfare \& INST'Ns Code $\$ 634$.

03 See Cal. Stats. 1937, ch. 369, §638, as amended; Cal. Stats. 1937, ch. 369, §721, as amended (formerly CAL. WELFARE \& INST'NS CODE $\$ \S 638,721$ ).

64 See Cal. Welfare \& Inst'ns Code \$ 551. Prior to 1961, the law authorized the judges of the superior court to designate one or more of their number to serve for a year as juvenile court judge. Cal. Stats. 1937, ch. 369, $\$ 572$ (forinerly CAL. WeLFARE \& INST'NS CODE $\$ 572$ ).

65 This is done in five counties. COMMS'N REPORT pt. II, at 5.

60 COMON'N REPORT pt. II, at 4-5. 
the juvenile court bench may make annual selections a problem; but apparently the individual superior courts must provide their own solutions. ${ }^{67}$

Previously, an apparently widespread problem was the unfamiliarity of judges with the juvenile system upon initial assignment to the court. ${ }^{68}$ The California Judicial Council now is directed to conduct annual statewide conferences of juvenile court judges and referees in order, partly, to provide orientation training for juvenile court judges on initial assignment. ${ }^{69}$ It is submitted that the publication of a comprehensive training manual by a subcommittee of the conference not only would provide the new juvenile court judge with immediate and thorough reference materials, but also would free the conference for more particularized study of special problems.70

\section{Referees}

A referee is a hearing officer, with the powers of a juvenile court judge, who liears the cases that are assigned to him by the presiding judge of the juvenile court. ${ }^{71}$ Previously, all referees' orders had to be approved by the juvenile court

67 Where some means of annual appointment or designation is the procedure used, presumably selection is based on interest; yet none of the judges of a particular court may desire or feel adequately suited for the assignment. The juvenile court bench has traditionally been soinewhat unpopular with superior court judges. CoMar's REPORT pt. II, at 26-27. In the long run, the uniform adoption of an annual or biennial rotation systen may have some advantages over designation on the basis of interest. Such a system, by making the post a part of every judge's experience, might ultimately raise the status of the juvenile court. Rotation might also insure a capable and experienced reserve of judges in times where juvenile court business requires more than one judge. Finally, the certainty of assigninent would permit advance preparation-imcluding participation in available orientation programs-by prospective juvenile court judges. On the other hand, adoption of a rigid rotation system would seem undesirable to the extent it displaced those judges deeply concerned with the problems of juvenile delinquency who desire to make the juvenile court bench a career. The commission recognized the dilemma; but in not recommending a change in the law, the commissioners apparently considered it more desirable to leave the problem of selection to the individual superior courts. See COMIM'N REPORT pt. II, at 4-5, 26.

68 COMar's Report pt. II, at 25.

60 The overall purpose of the section is to promote greater uniformity and effectiveness in the juvenile court process through discussion. CoMar'N REPORT pt. I, at 49.

${ }^{70}$ The conference's first meeting was confined to the discussion of selected portions of the new law. Cad. Judictal Councan, Proceedings of the First Annual Institute for JUVENIIE COURT JUdGeS AND REFEREES at ii (1962). Currently, faculty members at the University of California School of Criminology at Berkeley are preparing curriculum materials dealing with various phases of the juvenile court process. The study is sponsored by the President's Committee on Juvenile Delinquency and Youth Crime in conjunction with the United States Department of IJealth, Education, and Welfare under 75 Stat. 572 (1961). Perhaps these materials will provide a basis for the orientation program contemplated by the new law.

71 CAL. WeLFare \& INST'NS CODE $\$ 554$. Prior to 1961, the question arose whether a referee could conduct detention hearings as well as adjudicatory hearings. The previous statute stated that the detention hearing would be conducted by the "judge of the juvenile court." See Cal. Stats. 1949, ch. 1230, \& 1 (formerly CAL. WELFARE \& INST'NS CODE $\$ 729.5$ ). The point remains unclear under the new law. While CAL. WeIFARE \& INST'NS CODE $\$ 632$ directs that the minor be brought before a "judge of the juvenile court" for the detention hearing, all other provisions dealing with the conduct of the detention hearing refer inore generally to "the court." See CaI. WeIfare \& INST'NS Code \$\$ 633-39. The authority of the referee prescribed in $\$ 554$ would seem sufficiently broad to imclude service as a detention hearing officer; and at least some courts already employ referees in that capacity. See note 86 infra. 
judge, ${ }^{72}$ but the scope of referee activity has been broadened to relieve the juvenile court workload. Court approval is required only in cases where the referee's order would remove a minor from his home; in other cases, provision for such approval is left to the discretion of each juvenile court. ${ }^{73}$ Consequently, a significant number of referee orders are effective immediately. A procedure for review upon request by the youth provides some checks upon these increased powers. Within ten days after receiving notice of the referee's findings and order, ${ }^{74}$ the youth or his parent may apply for a rehearing by the juvenile court judge. If a transcript of the hearing before the referee has been prepared and accompanies the application, the judge may grant or deny a rehearing on the basis of the transcript. ${ }^{75}$ If no transcript exists, rehearing must be granted upon application as a matter of right. ${ }^{76}$ In addition, the juvenile court judge, on his own motion, may order rehearing of any referee proceeding. ${ }^{77}$ All rehearings of referees' proceedings must be conducted de novo. ${ }^{78}$

Where a de novo rehearing is conducted, the judge in effect duplicates the referee's efforts, so there may be an unnecessary increase in the juvenile court workload if rehearings frequently are conducted solely because of the absence of a transcript. At present, transcripts of referee hearings are made only upon order by the judge. ${ }^{79}$ Statutorily requiring transcription in all cases would therefore seem advisable.

A double standard of review may result if courts tend to confine the rehearing procedure to cases where court approval of referees' orders is not already required. In cases where a minor has applied for a rehearing, courts may decide that denial of the application is justified if the order is already subject to court approval. Where a minor has not so apphed, the judge may not exercise his own power to order a rehearing if approval is already required. A propensity of courts to prefer a limited review of referees' orders is inferrable from the traditional practice of rendering approval on a perfunctory basis. ${ }^{80}$ Yet review by judicial approval may be less thorough than review under the rehearing procedure. For example, a minor may submit an application for review directed to all or any specific part of the order or findings when review is under the rehearing procedure. ${ }^{81}$ Moreover, where the application is granted, the pursuant de novo hearing enables the youth personally to present his case to the judge. There is no provision authorizing the minor to bring specific objectionable portions of the order to the judge's attention, by either written or oral presentation, when the judge's "approval" is the form of review. Since orders removing the minor from his home are subject to approval because such a disposition is deemed too serious to be effective without review, ${ }^{82}$

72 Cal. Stats. 1937, ch. 369, $\$$ 577-78 (formerly CaL. WeLFare \& INST'Ns Code $\$ \S 577-78$ ); Cal. Stats. 1939, ch. 380, \&1 (formerly CaL. Welfare \& IrsT'Ns Code § 578.1).

73 CAL. Welfare \& INST'NS CODE $\$ \S 555,557$.

74 The referee is required to serve upon the youth's parent a written copy of his order and findings, and written notice of the youth's right to apply for a rehearing. CaL. WeLrare \& INST'NS CODE § 554.

75 Cat. Wetfare \& Inst'ns Code $\$ 558$.

76 Ibid.

77 Cax. Welfare \& Inst'vs COde $\$ 559$.

78 Cat. WELFARE \& INST'NS CODE $\$ 560$.

79 CAT. WeLfare \& INST'NS CODE $§ 67 \%$.

${ }^{80}$ See COMM's REPORT pt. II, at 28. Although the judge appears to have the power to order a rehearing on his own motion in "approval" cases, it is doubtful that the power will be exercised by a judge who customarily renders approval on a pexfunctory basis.

81 See CaI. Welfare \& Inst'Ns Code $\$ 558$.

82 See CoMm's REPORT pt. I, at 36. 
the possible difference in thoroughness of review seems somewhat anomalous. In other cases, to the extent that review by "approval" differs from review by rehearing, the rights of minors to review may vary according to the county in which the case is heard.

No specific qualifications for referees were expressed clearly in juvenile court law prior to $1961{ }^{83}$ All referees appointed subsequent to 1961 "must have been admitted to [law] practice ... for at least five years or have had at least five years [sic] experience im probation work at the supervising level or have had a combination of such experience ... aggregating five years." 84 These qualifications seem to reflect a desire to acquire expert referees without substantially limitimg the sources of personnel. Nevertheless, "nonattorney" probation officers-even with supervisory experience-may be inadequately prepared to cope with the extensive procedural innovations of the revised law, such as the new evidentiary procedures and the provisions for increased participation by counsel. ${ }^{85}$ Furthermore, it is questionable whether the probation officer-referee can act impartially in a case in which he or one of his subordinates prepared the social study. ${ }^{86}$

83 Cal. Stats. 1959, ch. 1722, \&1 (formerly CaL. Welfare \& InsT'Ns Code \$ 575.1), provided in part that, insofar as practicable, the referee should have experience and background in one of the following fields of correction: sociology, law, education, or probation.

84 CaI. WeLfare \& Inst'Ns Code §553. Referce appointments prior to September 15, 1961, are not affected. The commission would have substituted the term "professional juvenile social work" for "probation work." ConeM'N REPORT pt. I, at 58 (proposed Cal. Welfare \& Inst'ns Code $\$ 553$ ). Presumably, this would have permitted credit for private social work experience.

85 An exasperated Los Angeles police captain discussed his experience with a referee in a recent hearing under CAL. WELFARE \& INST'NS CODE $\S 600$ involving a baby allegedly the victim of parental neglect:

The evidence included pictures of the baby and the home at the time the arrest was made. The pictures were introduced as evidence, and the attorney ... argued that the pictures were not admissible because the photographer was not in court to testify. He made a fervent argument based on this point, and the referee sustained his objection and refused to admit the pictures.

The captain bitterly remarks,

Obviously, this is not the rule of evidence pertaining to the admission of photographs, a fact known to any juvenile officer.

Collins, California's New Juvenile Court Law, Cal. Peace Officer, Nov.-Dec. 1962, pp. 5, 51. For the rule on the admission of photographs see Adams v. City of San Jose, 164 Cal. App. 2d 665,330 P.2d 840 (1958). Whether such a fact would be known to "any juvenile officer" is open to some question, but undoubtedly any lawyer-referee with five years' experience would have known better. Referees could be drawn from the ranks of defense counsel with more logic than from the probation department. Yet the commission concluded that referee candidates "with extensive experience and training in the fields of law and in youth corrections work, preferably in probation" were "not readily available in any significant numbers." Coms's REPORT pt. II, at 29. Perhaps such people could be found in greater numbers if counsel were encouraged to participate in juvenile court proceedings, and their experience in the juvenile court was treated as an equivalent to "youth corrections" work.

80 One juvenile court judge participating in the annual judges' conference gave this probable conflict of interest as a reason that his county employs probation office personnel as referees for detention hearings only. Car. Judrciar Councri, Proceednags of the First Annuad INSTITUTE FOR JUVENIIE COURT JUDGES AND REFEREES 118 (1962). It is not clear, however, why the same question of impartiahity might not arise at detention hearings where the supervising probation officer would be ruling on his subordmate's discretionary request for detention. 


\section{Probation Officer}

In juvenile court, the probation officer represents the interests of the minor and furnishes the court with such information and assistance as the court may require. ${ }^{87}$ His duties include subpoenaing witnesses to attend the hearing to prove the allegations of the petition, and compiling a social study upon which he must base his recommendations for disposition to the court. ${ }^{88}$

In the absence of counsel, it is said that the probation officer shares with the judge the duty of defending the juvenile. ${ }^{89}$ With the increased likelihood of counsel, there inay be a temptation for the probation officer to assume a more prosecutorial function in support of his social study. ${ }^{90}$ Although whether he is to remain neutral or take the position of an advocate is unclear, ${ }^{91}$ it seems essential that the probation officer's role under the new law be fully defined to facilitate his working harnoniously with both counsel and the juvenile court judge. The commission recommended that the California Youth Authority expand the probation standards and procedures, already developed by that body, in collaboration with county probation officers and the Cahiforina Probation, Parole and Correctional Association ${ }^{92}$ Formulation of such expanded standards might help to resolve the question of the probation officer's proper role in the hearing.

87 CAL. WELFARE \& INST'NS CODE $§ 581$.

88 CAL. WELFARE \& INST'NS CODE $\$ \$ 581,701,702$.

89 See Block \& Flynn, Delthquency: The Juventhe Offender in America Today 325 (1956).

${ }^{90}$ Probation officers without a legal background may have difficulty assuming the role of prosecutor not only because they may be less adept at presenting legal issues but also because they may be mistaken as to the implication of these issues. The point is illustrated by the following incident observed by one of the authors: After an unrecorded neglect hearing in which the mother's testimony was crucial, the referee decided, over the strenuous objections of the mother, to remove the child from the home. The mother, who was represented by counsel, appealed. In the subsequent de novo rehearing before the judge, she substantially changed her previous testimony. The probation officer, who had been present at the referee hearing, consulted with his supervisor and concluded that he could not impeach the mother since this was a "de novo" hearing, wlich he interpreted to mean that "everything" that had occurred before the referee "legally had never taken place." Consequently, the judge returned the child to the mother. There seems little doubt that such impeachment would have been proper. 3 WIGMORE, EvIDENCE $\$ 1040$ (2) (3d ed. 1940). In addition to testifying to the prior inconsistent statements for impeachment purposes, the probation officer or the referee probably could have introduced evidence to establish the truth of the previous statements as party admissions against interest. 4 id. $\$ 1051$.

91 CAI. WEIFARE \& INST'NS CODE $\S 701$ authorizes the probation officer to subpoena witnesses to prove the allegations of the petition where the juvenile has made an extrajudicial confession which he demes at the adjudicatory hearing. However, other provisions for the presentation of evidence at the hearing do not specifically designate any individual proponent of the allegations in the petition. For instance, $\$ 701$ provides, simply, that "any matter or information rclevant and material to the circumstances or acts which are alleged to bring [the minor] ... within the jurisdiction of the juvenile court . . . may be received in evidence." The statute's lack of clarity creates a number of problems. Perhaps it might be inferred from the explicit reference to the probation officer as the one to secure witnesses to prove the petition that he is to assume the role of prosecutor. If it is intended that someone other than the probation officer act as prosecutor, then it is not said whether the district attorney, city attorney, county counsel, or some other person is to do the job. Finally, perhaps the legislature intended that no one should be a "prosecutor" in the criminal law sense; but the probation officer, district attorney, or other person should be prepared to present, as informally as possible, facts sufficient to support the allegations of the petition.

92 COMMr's REPORT pt. I, at 35. 


\section{Counsel}

The new statutory provisions reflect the view that the right to be represented by counsel is a necessary element of every juvenile proceeding. ${ }^{93}$

\section{a. Right to Employ Counsel of Oren Choice}

California Welfare and Institutions Code section 679 provides: "A minor who is the subject of a juvenile court hearing and any person entitled to notice of the [adjudicatory] hearing ... has the right to be represented at such hearing by counsel of his own choice." Although this section expressly provides that a juvenile may employ counsel of his own choice at a juvenile court hearing, the language employed, together with the section's placement in that part of the code devoted to adjudicatory hearings, suggests that its coverage does not include detention hearings. The right to have counsel at the detention hearing is not elsewhere specifically acknowledged, and the traditional position seems to have been that counsel was not appropriate at this stage. ${ }^{94}$ Nevertheless, it seems unlikely that a court would bar counsel from the detention hearing. The language of the sections dealing with the conduct of the detention hearing clearly seems to contemplate the presence of counsel at that stage. ${ }^{95}$ Since the personal hiberty of the juvenile depends on the outcome of the detention hearing, the right to employ counsel at that stage should be made exphcit either by appropriate amendment of section 679 or by addnig a new section pertaining to the detention hearing.

\section{b. Right of Indigent Youth to Appointed Counsel}

The juvenile has a right to counsel when he has committed an act of felonious proportions and desires an attorney but cannot afford one. The court has discretion in appointing a lawyer in nonfelony cases. ${ }^{96}$ The legislature departed from

83 See Cosar's Report pt. I, at 26. The old statute was silent in regard to the juvenile's right to counsel. Case law established the right of a youth to employ counsel, People ex rel. Weber v. Fifield, 136 Cal. App. 2d 741, 289 P.2d 303 (1955), and hinted that failure to advise the juvenile of his right to counsel may deprive him of due process in certain instances, People v. Dotson, 46 Cal. 2d 891, 895, 299 P.2d 875, 877 (1956):

The fact that a minor is not represented by counsel need not be a demal of due process in the juvenile court. . . . It is only when by such lack of representation of the minor undue advantage is taken of him or he is otherwise accorded unfair treatment resulting in a deprivation of his rights that it can be said he has been demied due process of law.

Otherwise, juveniles had neither the rigbt to be advised of right to counsel, nor right to appointment of counsel in cases of indigence. This has been the traditional position in other states as well. See Akers v. State, 114 Ind. App. 195, 51 N.E.2d 91 (1943); Dudley v. State, 219 S.W.2d 574 (Tex. Ct. Civ. App. 1949). Contra, Shioutakon v. District of Columbia, 236 F.2d 666 (D.C. Cir. 1956).

94 See Cosni's Report pt. II, at 78.

95 CAL. WeIfare \& INST'NS CODE $\$ 633$ provides that, at the detention hearing, the court must inform the youth of his right to be represented at every stage of the proceedings by counsel. CAL. WELFARE \& INST'NS CODE $\$ 634$ provides for appointment of counsel in certain cases at the detention hearing. CAI. WELFARE \& INST'NS CODE $\$ 635$ directs the court, at the detention hearing, to hear such relevant evidence as the minor's counsel, among others, desires to present.

06 See CaL. Welfare \& InsT'NS Code $\$ 634$ (applicable to the detention hearing) and $\$ 700$ (applicable to the adjudicatory hearing). The distinction between mandatory appointment in felony cases and permissive appointment in other cases seems odd in view of the fact that all young law violators are grouped as a single class in CAI. WELFARE \& INST'NS CODE $\$ 602$, upon 
the recommendation of the commission ${ }^{97}$ supplying a legislative view that counsel may not be necessary in all cases. These provisions for counsel are new in California, and it is unclear what factors judges in various counties should consider in exercising their discretion to appoint counsel in nonfelony cases. The statute specifies no applicable criteria, and case law has not yet clearly developed on the point. ${ }^{98}$ For two reasons, it is possible that the permissive provisions pertaining to nonfelony cases may be seldom exercised in some counties. (1) It seems to have been the tendency of some courts under the old law to discourage the participation of counsel in juvenile court proceedings. ${ }^{99}$ (2) The burden of court appointments on the local bar may persuade some courts to minimize the number of such appointments. For instance, although the new law promotes participation by the bar in juvenile proceedings, the legislature failed to enact the commission's recommendation that compensation be provided for attorneys appointed by the court. ${ }^{100}$ Where public defender offices exist, their scope of operation is limited to cases arising under sections 601 and $602 . .^{101}$

\section{c. Right to be Advised of the Right to Employ Counsel}

The revised statute provides three different ways in which the juvenile court is to advise a youth of his right to retam counsel of his own choice. (1) Where a petition is filed on behalf of a youth, written choice of the time and place of the adjudicatory hearing, together with a copy of the petition, must be served upon the parent or guardian of the youth. ${ }^{102}$ This notice must state that the minor is entitled to have his attorney present at the hearing on the petition. ${ }^{103}$ (2) Where a detention hearing is conducted to determine whether a youth should be detained pending the adjudicatory hearing, the court must imform the youth of his right to be represented by counsel at every stage of the proceedings. ${ }^{104}$ (3) At the

which juvenile court jurisdiction rests. The distinction would not seem justified if it was intended merely to minimize the participation of counsel in juvenile proceedings. If the distinction was intended to provide an extra safeguard for youths charged with felonious conduct in case they are certified to criminal court for prosecution, then the question arises whether the distinction also was intended to imply that attorneys should adopt an adversary posture in such cases.

97 The commission recommended that the court be required to appoint counsel in all cases upon the request of an indigent youth. COMN'N REPORT pt. I, at 27 (proposed Cal. Welfare \& Inst'ns Code $\$ \$ 633,700$ ).

98 Language in People v. Dotson, 46 Cal. 2d 891, 895, 299 P.2d 875, 877 (1956), suggests that due process should impose outside limits to discretion. There is no assurance, however, that Dotson will be followed by future courts. In re Patterson, 58 Cal. 2d 848, 377 P.2d 74, 27 Cal. Rptr. 10 (1962), decided under the new law, suggests that any limitations on discretion will be founded upon rigid statutory construction rather than notions of substantive due process. In that case, it was alleged that a juvenile had committed burglary. Though apparently indigent, he was not represented by counscl. The court said, "If . . . the parent has not indicated any desire for counsel, the court has no obligation to appoint counsel, and its failure to do so did not vitiate the judgment entered." Id. at 852, 377 P.2d at 77, 27 Cal. Rptr. at 13.

99 COMAN'N REPORT pt. II, at 12-13.

100 Attomeys appointed by the juvenile court in all cases (including felonies) must serve without compensation. 38 Ops. CAL. ATr'y GEN. 154 (1961). The Commission recommended that attorneys appointed by the juvenile court.be compensated in the same manner as counsel appointed in criminal courts. CoMM'N REPORT pt. I, at 67; see CAL. PEN. CODE §987a.

101 CAI. Gov'T CODE § 27706(e).

102 CAL. WELFARE \& INST'NS CODE $\S 658$.

103 CaL. Welfare \& Inst'Ns Code $\$ 659$ (e).

104 CaL. WeIfare \& INST'NS Code $\$ 633$. 
adjudicatory hearing, the judge must ascertain whether the youth has been informed of his right to be represented by counsel. If the youth has not been so informed, the judge must advise him of his right to have counsel present. ${ }^{\mathbf{1 0 5}}$

Since a youth who has been retained in custody probably has a right to employ counsel at the detention hearing, ${ }^{106}$ it seems important to determine whether the advice provisions adequately inform him of this right. In the case of a detained youth, a probable sequence of events under the revised statute will be: (1) the probation officer's filing a petition to invoke the jurisdiction of the juvenile court; (2) oral or written notice of the time and place of the detention hearing; ${ }^{107}$ (3) the detention hearing; and (4) the adjudicatory hearing. ${ }^{108}$ Given this sequence, the written notice accompanying service of the petition probably will be received by the youth's parent or guardian prior to the detention hearing. ${ }^{109} \mathrm{How}-$ ever, since the statement in the written notice pertains to the right to counsel only at the hearing on the petition, this notice may not effectively acquaint the youth or his parent of his rights at the detention hearing. ${ }^{110}$ Hence, the youth's first notification of these rights probably will occur at the detention hearing itself, although the law permits only one day's continuance to allow an attorney to acquaint himself with the case.111 Extending the time for continuance would seem unwise since usually the youth is already detained. It would seem more fair to insure that the youth has notice of his right to counsel im advance of the detention hearing by requiring not only that such advice be contained in notice of the detention hearmg but that the advice be directly communicated to the youth. ${ }^{112}$

Where the youth has not been detaimed, a detention hearing will not have been conducted. Information concerming the youth's right to employ counsel at the adjudicatory hearing is supplied only by the written notice accompanying service of the petition, and, where the court has ascertained the youth's lack of such information, by the court at the adjudicatory hearing. At the adjudicatory hearing, the judge need not verbally "ascertain" whether the child has been so advised where the court record indicates that he has been. ${ }^{113}$ This suggests that there may be cases in which the youth in fact is not advised of his right to employ counsel.

105 CaL. WeLtare \& Inst'Ns CODE $\$ 700$.

106 See text accompanying note 95 supra.

107 Notice of the time and place of the detention hearing is transmitted to the minor's parent or guardian by the probation officer and may be oral. CAL. Werrare \& INST'NS CODE $\S 630$. Notice of the time and place of the adjudicatory hearing is transmitted by the clerk of the juvenile court and must be written. See CaL. Weifare \& INST'Ns CoDE $\$ \S 658-59$. If the legislature should decide to include information regarding counsel in the notice of the detention hearing, it may be advisable to require that notice be written.

108 See Car. Wetrare \& Insr'ins Code $\$ \S 630,65 \%$.

109 Compate Cat. Welfare \& Inst'ns Code \$ 657, with Cax. Welfare \& Inst'ins Code $\S 658$.

110 See Car. Weifare \& Inst'ns Code § 659(e).

111 See CaL. WeLfare \& INST'NS Code $\$ 638$.

112 Notice of the detention hearing is communicated to the parent or guardian of the youth, but not to the youth himself. Cax. WeLrare \& INST'NS CODE § 630. It would seem advisable to directly inform the youth of his right to counsel in view of the possible conflicts of interest which nuy exist between parent and child. See note 62 supra.

${ }_{113}$ In re Patterson, 58 Cal. 2d 848, 377 P.2d 74, 27 Cal. Rptr. 10 (1962) (three dissents). Patterson's nother had been personally served with notice of the hearing on the petition, which notice contained the statement regarding counsel required by CAL. WEIFARE \& INST'NS CODE $\$ 659$. The boy also had been advised of his right to counsel at his detention hearing. The court records reflected both events. $58 \mathrm{Cal} .2 \mathrm{~d}$ at 851-52, 377 P.2d at 76-77, $27 \mathrm{Cal}$. Rptr. at 12-13. 
The record may be erroneous in showing that advice has been given; or the record may correctly relate the service of written notice, but the written notice may not adequately advise the youth. For example, his parent may not read English, or may not understand thoroughly the content of the notice. Since notice is sent only to parents or guardians, the juvenile may not know of his right to counsel if there is an absence of communication between parent and child. ${ }^{114}$ The parent may waive service of notice by a timely appearance in court, ${ }^{115}$ seemingly waiving also the information contained in the notice regarding the right to counsel. Due process may not, except in certain cases, require that waiver of the right to retain counsel be based on adequate knowledge of the right to have counsel in the juvenile process. ${ }^{116}$ Nevertheless, the inclusion of the advice provisions in the revised statute certainly manifests a legislative intent that informed waiver be required by the juvenile court act. ${ }^{117}$

\section{d. Right to be Advised of the Right to Appointed Counsel}

The right of an indigent youth to counsel appointed by the court depends upon the youth's request for such counsel. ${ }^{118}$ Although it would seem important that the youth have full knowledge of his right to request a lawyer, there may be situations in which the advice provisions do not afford adequate information. For example, an indigent youth who has been detained in custody might not be told at the detention hearing that he may request appointed counsel. ${ }^{110}$ Although the written notice served with the petition upon the youth, parent, or guardian inentions the youth's right to request appointed counsel, the circumstances surrounding the service of this notice may deny the youth this information. ${ }^{120}$ Hence, there may be cases in which an indigent youth does not request appointed counsel at his detention hearing because he does not know of his right to make such a request. The result seems not only unfair but inconsistent with the otherwise broad advisory provisions of the new law. ${ }^{121}$

114 See note 62 and accompanying text stcpra.

116 Cat. WeIfare \& INST'NS CODE $\$ 660$.

116 See note 93 sutpra.

117 Justice Traynor, dissenting in In re Patterson, supra note 113, strongly urged that the majority rendered CAL. WELFARE \& INST'NS CODE $\S 700$ superfluous by failing to read it to require the judge to determine whether the absence of counsel at the hearing is the result of an informed waiver of the right to counsel by the youth. $58 \mathrm{Cal} .2 \mathrm{~d}$ at $853,377 \mathrm{P.2 \textrm {d }}$ at 78, 27 Cal. Rptr. at 14. See Shioutakon v. District of Columbia, 236 F.2d 666 (1956) (where right to counsel exists, court must be assured that any waiver thereof is intelligent). The holding in Patterson suggests that at least a slim majority of the California Supreme Court may uphold any practices valid prior to 1961 unless the practices were changed by unequivocal language in the statute. The possibility of such resistance in the appellate courts emphasizes the need for explicit expressions of innovation embodied in the revised statute.

118 See CaL. Welfare \& INsT'Ns Code $\$ \S 634,700$. The Patterson majority made this point clear. See note 98 supra.

110 The legislature rejected the commission's recommendation that detained juveniles be advised routinely at the detention hearing of the right to appointed counsel. Compare CoMM'N RePORT pt. I, at 67 (proposed Cal. Welfare \& Inst'ns Code §632), with CaL. Welfare \& INST'NS CODE $\S 633$.

120 See text following note 113 supra.

121 As for the adjudicatory hcaring, it has already been suggested that some youths may receive no information regarding counsel as a result of the Patterson decision, which indicates that the judge does not have a duty to inform the youth where the court record shows that written notice has been transmitted to a parent or guardian. See text following note 112 sttpra. 


\section{B. Hearings}

\section{Detention Hearing}

Where the probation officer decides that a juvenile should be detained. the juvenile court must be notified within forty-eight hours for the purpose of scheduling a detention hearing. ${ }^{122}$ A petition filed by the probation officer serves as notice to the court; the hearing follows the filing of the petition by no more than one day. ${ }^{123}$ This approach may promote delays in conducting the detention hearing. Since the petition appears to be required before the detention hearing is begun, probation officers-needing time to conduct the investigation, prepare their reports, and draft the petition-may detain youths as a matter of course for the full forty-eight hour period. ${ }^{124}$ This would seem inconsistent with the objective of reducing Cahifornia's high detention rate partly by providing for early and effective detention hearings. ${ }^{125}$

The minor must be present at the detention hearing, and the judge must hear "relevant evidence" regarding the detention criteria. ${ }^{126}$ Apparently the sole purpose of the detention hearing is to provide a judicial review of the peace officers' determination that the criteria for detention have been met. ${ }^{127}$ Yet facts bearing on whether the juvenile should be adjudicated a ward or a dependent child-particularly in cases of serious offenses-nuay well be "relevant evidence" at the detention hearing. The extent to which statenients made by the juvenile at the detention hearing may be used at the later adjudicatory hearing is unclear. It is

122 CAL. WELFARE \& INSr'NS CODE $\$ 630-31$. If action is not taken within the forty-eight hours, the youth must be released. Prior law was essentially the same. Cal. Stats. 1949, ch. 1230, $\$ 1$ (formerly CAL. WELFARE \& INST'NS CODE $\$ 729.5$ ).

123 CAL. WEIFARE \& INST'NS CODE $\$ 630$ provides, "If the probation officer determines that the minor shall be retained in custody, he shall immediately file a petition ... with the clerk of the juvenile court who shall set the matter for hearing on the detention hearing calendar. ..."

Cat. Welfare \& Inst'ns Code $\S 632$ provides,

[A] minor taken into custody under the provisions of this article shall be brought before a judge of the juvenile court for a hearing (which shall be referred to as a "detention hearing") to determine whether the minor shall be further detained, as soon as possible but in any event before the expiration of the next judicial day after a petition to declare such minor a ward or dependent child has been filed. ...

Previous law was substantially the same. Cal. Stats. 1949, ch. 1230, § 1 (formerly CAL. WeLFARE \& INST'NS CODE \& 729.5). The commission proposed that the probation officer alert the court by notice to the clerk immediately upon his decision to detain; the detention hearing was required to be held as soon as possible within the forty-eight hour time himit. Hence, although a petition on behalf of a detained youngster had to be filed within the forty-eight hour time himit, failure to file a petition until the end of the forty-eight hour period would not prevent an earher detention hearing from being conducted. COADM's REPORT pt. I, at 66-68 (proposed Cal. Welfare \& Inst'ns Code \$\$ 630-31, 639).

124 See Conar's REPORT pt. I, at 42, indieating that this practice existed under the old law. A possible sanction would be habeas corpus; another would be a false imprisonment civil suit against the probation officer. Although it is difficult to win a false imprisonment suit, perhaps the threat of having to defend would deter such practice. See, e.g., Dragna v. White, 45 Cal. 2d 469, 289 P.2d 428 (1955); Lincoln v. Grazer, 163 Cal. App. 2d 758, 329 P.2d 928 (1958).

125 See COMan's Report pt. I, at 41.

126 See Cal. Wetfare \& Inst'ns Code $\$ \$ 632,635$.

127 Under CAL. WELFARE \& INST'NS CODE $\$ \S 635$ and 636 , the criteria upon which a judge must base his order to detain the youth are the same as those provided for in Cax. WeLrare \& INST'NS CODE $\$ 628$, pertaining to the probation officer. See text preceding note 50 supra. 
also unclear whether such statements could be used as evidence against the youth should his case be transferred to criminal court for prosecution. ${ }^{128}$

\section{Adjudicatory Hearing}

If a petition is filed, an adjudicatory hearing must be conducted within thirty days after filing or, if the youngster is being detained, within fifteen days after filing. ${ }^{129}$ The adjudicatory hearing essentially is a bifurcated hearing. First, the court determines the "jurisdictional question" of whether the minor is a person described by sections 600,601 , or 602 of the California Welfare and Institutions Code. ${ }^{130}$ If the court finds that it has jurisdiction, then it proceeds to a consideration of the proper disposition to be made of the minor. ${ }^{131}$ Some important changes inade by the 1961 revision of the juvenile court law concern the informality of the adjudicatory hearing, the persons permitted to be present at the hearing, and the rules of evidence employed at the hearing.

\section{a. Informality}

Except where there is a contested issue of fact or law, the adjudicatory hearing must be conducted in an informal nonadversary atmosphere with a view to obtaining the maximum co-operation of the youngster. ${ }^{132}$ The exception for contested cases was not recommended by the commission. ${ }^{133}$ Courts may interpret the proviso to mean that, where the minor denies the allegations of the petition, the adjudicatory hearing should follow the familiar format of the criminal or civil trial. ${ }^{134}$ Such a posture seems neither consistent with the juvenile court rehabilitative philosophy nor necessary to a fair hearing on contested issues. ${ }^{335}$

\section{b. Persons Present at Hearing}

The adjudicatory hearing must be private, except when the public is requested by the minor or when certain persons deemed to have a direct and legitimate interest in the case are admitted by the judge. ${ }^{136}$ Presumably the judge could admit a newspaper reporter, ${ }^{137}$ a research worker, or a student; but the statute specifically precludes him from admitting-except as a witness-any person on trial, awaiting trial, or under accusation of crime, other than a parent, guardian,

128 Such statements may be barred from use in a subsequent criminal procceding. Sce Harling v. United States, 295 F.2d 161 (D.C. Cir. 1961); Note, 50 CArF. L. REv. 902 (1962). 129 CaI. WeLFare \& INST'NS CODE $§ 657$.

130 CAI. WELFARE \& INST'NS CODE $\$ 701$.

131 CAL. WELFARE \& INST'NS CODE $\$ 702$.

132 CAL. Wetfare \& INST'NS CODE $\$ 680$.

133 See COMOM'N REPORT pt. I, at 73 (proposed Cal. Welfare \& Inst'ns Code $\$ 680$ ).

134 Prior to 1961, some courts made a practice of regularly certifying contested cases to criminal courts. Note, The California Juvenile Court, 10 StAN. L. Rev. 471, table I (1958).

135 See Comor's Report pt. I, at 12 ; U.S. ChImpers's Bureau, Dep't of Healtr, Education, and Welfare, Standards for Specialized Courts Deauing With Children 54-56 (1954); Alexander, Constitutional Rights in Juvenile Court, 46 A.B.A.J. 1206 (1960).

138 CAI. WEIfARE \& INST'NS CODE \$§ 675-76. This appears to be a change of emphasis more than of substance from the former statute which provided for privacy upon the request of the youth or in the discretion of the judge. Cal. Stats. 1937, ch. 369, \& 733 (formerly Car. WELFARE \& INST'NS CODE § 733).

137 See comment to National Probation \& Parole Ass'n, Standard Juvenile Court AcT $\$ 19$, at 49 (1959), which would encourage newspaper reporters to attend on the condition that they did not report names. 
or relative of the minor. ${ }^{138}$ Since the statute concerns the persons other than the youth who may observe the hearing, it is unclear whether several minors accused of the same offense inust be given separate hearings. ${ }^{139}$

\section{c. Evidence}

The revised statute creates a distinction between "admissible" evidence and what may be termed "quality" evidence. At both the liearing on jurisdictional facts and the hearing on disposition, evidence is admissible that is "relevant and inaterial" to the issues involved in the respective hearings. ${ }^{140}$ At the lrearing on jurisdictional facts, however, the court's findings must be supported by a preponderance of "quahty" evidence. When jurisdiction is based on section 602 of the Welfare and Institutions Code, "quality" evidence is that which would be legally admissible in criminal proceedings. ${ }^{141}$ When jurisdiction is based on sections 600 or 601 , "quality" evidence is that which would be legally admissible in civil proceedings. ${ }^{142}$

Apparently the distinction between "admissible" evidence and "quality" evidence was enacted to permit the use of "nonquality" evidence of probative value. ${ }^{143}$ Even if this distinction is preserved, there is a question whether probative "nonquality" evidence can be given any weiglt by the referee or judge determining jurisdiction. For example, the opinion of a neiglibor that a juvenile has delinquent propensities inay be relevant and material to determining whether the juvenile is a person described by section 601 . Consequently, this opinion would seem to be admissible at the adjudicatory liearing, but-to be consistent with the law-it could not be considered by the judge or referee since it would not be admissible in civil actions. ${ }^{144}$

The difficulty in applying these standards of evidence may prevent inaintaining the distinction between "admissible" evidence and "quality" evidence. In addition to excluding relevant but "nonquality" evidence from his determination of the weiglit of the evidence, the judge often may be required to juggle the criminal and civil standards of weight when jurisdiction is invoked under both

138 CAL. WeLFARE \& INST'NS CODE $\$ 675$.

139 It wquld seem to be the better practice to determine jurisdiction en masse but to hold separate dispositional hearings for each. This procedure would permit the judge to piece together the total story by adroit questioning and ensure that the dispositional treatment is individualized. Of course, each minor should be provided with his own defense counsel, and each minor should be protected from bearing the burden of proving his nonparticipation; positive evidence of participation should be adduced other than inere statements by various minors that "we were all in it together." In such situations an innocent minor may be in no position to "inform on" others with whom he subsequently must hive. Interviews with Juvenile Bureau officers indicate that youths, much more than adults, are sensitive to the impact that their statements may have on their peers.

140 Cat. Welfare \& Inst'ns Code $\$ 701,706$. These sections fill a hiatus that existed prior to 1961 by providing statutory standards of admissibility and weight of evidence. Under the old law, some courts used criminal rules; some used "relaxed" criminal rules, retaining reasonable doubt as the measure of weight; some used "relaxed" criminal rules, employing "preponderance of evidence" as the standard for weight. Note, The California Iuvenile Court, 10 STAN. L. REv. 471, table I (1958); see CoMar's REPORT pt. I, at 29.

141 CAT. Welfare \& INST'NS CODE $\$ 701$.

142 Ibid.

143 COMM'N REPORT pt. I, at 30.

144 McCorarick, EvDEnCE §11 (1954); 7 Wrgarore, Evmence $\$ 1918$ (3d ed. 1940). 
sections 601 and $602 .{ }^{145}$ Properly applying these rules may be difficult for the veteran judge, and unquestionably will prove difficult for the referee who may have no legal background from which to draw. "Nonquality" evidence may be of considerable value to the court in deciding whether it has jurisdiction, and controlled use of this sort of evidence apparently has been successful in other fields of law. ${ }^{146}$ However, if "nonquality" evidence is to be given weight in the court's decision, explicit rules defining the nature and extent of the weight to be given seem needed.

The proper role of the probation officer's report at the adjudicatory hearing is a problem as a consequence of the present differentiation between questions of jurisdiction and disposition. It seems clear that the primary function of the report is to aid the court in determining disposition. ${ }^{147}$ In the past, however, the report has been used as a source of facts for the initial question of jurisdiction. ${ }^{148}$ To be consistent with the provisions for a bifurcated hearing, the court should not consider those portions of the report relating to treatment until the jurisdictional issue has been determined. Nevertheless, the probation officer is not required to separate the issues of jurisdiction and disposition in his report. If the entire report continues to be made available to the court at the time when the question of jurisdiction is being decided, so-called dispositional facts may receive probative force not intended by the legisiature.

The bifurcated hearing concept also may suffer from the provision authorizing the juvenile court to certify certain youths to criminal court for prosecution. In deciding whether to certify a case to criminal court, the judge must make two findings: (1) he inust find that substantial evidence has been adduced that the offense alleged is punishable as a felony under criminal law; and (2) he must find that the youth would not be amenable to treatment within the juvenile court process. ${ }^{149}$ The judge may inake these findings and certify the juvenile to criminal court at any time during the adjudicatory hearing. ${ }^{150} \mathrm{It}$ would seein advisable to postpone the question of certification until the disposition stage of the bifurcated proceedings. ${ }^{151}$ Determining this issue at the jurisdictional stage probably would not save much tine, ${ }^{152}$ and is unlikely to prevent the admission of evidence that subsequently could be used against the youth in the criminal proceeding. ${ }^{153}$

145 The possibibity of invoking jurisdiction under two different sections seems to have been contemplated by $\S 656(\mathrm{c})$, which states that the petition should specify "the code section or sections and subdivision or subdivisions under which the proceedings are instituted." Cax. WELFARE \& INST'NS CODE $\$ 656$ (c).

146 Sec, e.g., California Administrative Procedure Act $\$ 11513$ (c), CaL. Gov'T Cone $\S 11513$ (c); Benedetti v. Department of Alcoholic Beverage Control, 187 Cal. App. 2d 213, 9 Cal. Rptr. 525 (1960).

147 See CaL. Welfare \& Inst'ns Code $\$$ 580-82, $702,706$.

148 See, e.g., In re Halamuda, 85 Cal. App. 2d 219, 192 P.2d 781 (1948) (probation officer's report sufficient in itself to support adjudication of dependency).

149 CAL. Welfare \& InsT'NS CODE $\$ 707$.

$150 \mathrm{Ibid}$.

151 This was recommended by the commission. COMMM'N REPORT pt. I, at 76 (proposed Cal. Welfare \& Inst'ns Code $\$ 725(\mathrm{c}))$.

152 Both jurisdiction and disposition are hikely to he decided on the same day. See Comar'v REPORT pt. II, at 16.

153 The juvenile court "double jeopardy" statute does not bar evidence adduced in juvenile court froun subsequent criminal proceedings initiated by certification of the case froin juvenile court. CAT. WELFARE \& INST'NS CODE $\S 606$. It may be argued that certification as early in the proceedings as possible is a desirable device for avoiding the admission of some evidence 
Furthermore, the fundamental reason for certification would seem to be the "unfitness" of the youth for juvenile treatment; the question of treatment should be considered only after jurisdiction has been determined under the bifurcated process.

\section{IV}

\section{MEASURES TO CURTAIL POSTADJUDICATION STIGMA}

An order adjudging a minor to be a ward of juvenile court is not considered to be a conviction of a crime for any purpose, nor is the juvenile court proceeding deemed criminal in nature. ${ }^{154}$ Nevertheless, public access to fingerprint records, arrest information, and juvenile court records may threaten the youth with a reputation as disabling as if his exposure had been to the criminal process. ${ }^{155}$ Accordingly, the new act controls public use of such information.

\section{A. Fingerprints and Arrest Information}

Prior to 1961, the California Welfare and Institutions Code contained no provisions specially applicable to the transmission of fingerprints and arrest data between law enforcement agencies and to and from the two major centers of criminal statistics-the California Bureau of Criminal Identification and Investigation (CII), and the Federal Bureau of Investigation. ${ }^{156}$ At present, only CII is prohibited from transmitting fingerprint and arrest information unless it includes a record of the disposition resulting from the arrest or excludes arrest information altogether. ${ }^{157}$ To the extent that other agencies make this information available without indicating the ultimate disposition of the juvenile, it is possible that the youth will be subject to public embarrassment as a consequence of his exposure to the juvenile court process.

in the juvenile court proceeding which would subsequently be used against the youth in the criminal proceeding. The validity of this approach is questionable in light of the requirement that certification be preceded by a determination that substantial evidence supports the finding that the youth has committed an act of felonious proportions. Also, it has been suggested that evidence adduced in juvenile court may not be usable at subsequent criminal proceedings notwithstanding $\S 606$. See note 128 suppra.

154 Cat. WeLfare \& INST'Ns Code \$ 503; In re Shubert, 153 Cal. App. 2d 138, 313 P.2d 968 (1957); see People v. Gomez, 152 Cal. App. 2d 139, 313 P.2d 58 (1957) (youth's prior adjudication as delinquent cannot later be used to impeach him as witness).

155 See CoMrar's Report pt. II, at 110.

156. Juvenile records apparently received the same treatment as adult criminal records. See Cat. Pen. Code $\$ \S 11107,11112$.

157 CaL. WeIfare \& INST'NS CODE $\$ 504$. The commission proposed a statute which prohibited agencies (including law enforcement agencies) from knowingly transmitting to CII or FBI any fingerprint, photograph, or arrest information concerning a youth under eighteen years old uniess the juvenile court had taken dispositive action in the case, and documentation of that action accompanied the transmitted record. CoMar'N REPORT pt. I, at 52 (proposed Cal. Welfare \& Inst'ns Code $\$ 504$ ). "Dispositive action" by the court could be either a disposition following a determination of the issue of wardship or certification to criminal court for prosecution. Ibid. The prohibition did not apply to transmissions from one law enforcement agency to another for identification purposes-so long as any information concerning arrest of the youth was not included. Ibid.

The proposed statute was designed to prevent possibly misleading arrest records from building up prior to final disposition by the court and to insure that correct inferences would be drawn from records transmitted subsequent to disposition. COMMr's REPORT pt. I, at 47. Section 504 constitutes a rejection of this proposed control of fingerprints and arrest information at the law enforcement agency level. 


\section{B. Juvenile Court Records}

Since juvenile court records constitute a potential major source of stigmatization, the statute limits public access to such records. The petition and probation reports are exempt from unauthorized public perusal. ${ }^{168}$ After five years from the termination of juvenile court jurisdiction over a youngster, two devices are available for keeping private the numerous other records emanating from juvenile court proceedings. (1) The court or probation officer may destroy all such records, papers, and exhibits except the juvenile court record, any minute book entries, dockets, judgment dockets, and probably arrest records. ${ }^{160}$ (2) Upon petition of the youth or the county probation officer, the court may, when satisfied with the youngster's reformation, order sealed all records pertaining to the child's juvenile court experience-including those records exempt from destruction by the court. ${ }^{160}$ Where the records are sealed, the proceeding shall be deemed never to have occurred, and the former ward properly may reply accordingly to any inquiry. ${ }^{161}$

Since the time at which records may be destroyed or sealed depends upon the time at which juvenile court jurisdiction terminates, the protection afforded by these measures may be impaired in some counties by possible variations in the criteria used in terminating jurisdiction. Present law merely provides that the court may retain jurisdiction over any ward or dependent child until age twentyone. ${ }^{162}$ This would seem to permit a routine practice of retaining jurisdiction over

158 CaI. Welfare \& INST'NS CODE $\$ 827$ reads: "A petition filed in any juvenile court proceeding and any reports of the probation officer ... may be inspected only by court personnel, the minor ...., his parents ...., and the attorneys for such parties, and such other persons as may be designated by the judge. ..."

159 CAT. WeIfare \& INST'NS CODE $\$ 826$. The "juvenile court record" is a written record of the judge's order and findings. CAT. WEIFARE \& INST'NS CODE $\$ 825$.

$160 \mathrm{CAL}$. WeIfaARE \& INST'NS CODE $\S 781$. The section expressly is made applicable to records in custody of other state "agencies." Presumahly the prohation department, law enforcement agencies, and the California Bureau of Criminal Identification and Investigation are included.

Since the sealing provision provides somewhat broader coverage than the destruction provision, it seems especially important that the youth knows of his right to petition for a seahing order. It would seem proper to include notice of this right in any order by the court terminating jurisdiction over the youth. CAI. WELFARE \& INST'Ns CODE \&778 does not now require such notice.

161 CAL. WeLFare \& InsT'Ns Code $\$ 781$. A proper answer of the court or agency to an mquiry concerning a possible past "record" of the former ward would be: "We have no record on the named individual." 40 OPS. CAL. ATr'y GEN. 50 (1962). If a former ward is asked on an official document whether he has ever had any court records expunged, it remains unclear whether he inust reveal the fact that he is the subject of juvenile court records which have been sealed. See, e.g., Comm. of Bar Examiners, State Bar of California, Registration as a Law Student, question 5, 1963.

Clearly, neither the destruction nor the sealing provision can be enforced as to records in the custody of the FBI. However, it would seem advisable to provide machinery whercby a copy of the court's sealing order is forwarded for information purposes to the FBI. If the FBI cannot seal its records in cooperation with the California agencies, at least the FBI records will refiect the judgment of the court that reformation of the youth has been sufficient to warrant the sealing order.

162 CaI. WELFARE \& INST'NS CODE $\$ 607$. The former law provided that the court inust retain jurisdiction over 2 ward until he rcaches twenty-one years of age or until the court is satisfied that the ward has fully reformed or that further direction and supervision are unnecessary or inadvisable. CaL. Weifare \& Inst'ns Code \$ 750; People v. Sanchez, 21 Cal. 2d 466, 132 P.2d 810 (1942). 
a juvenile until he is twenty-one unless the minor or his parents petition for earher termination. ${ }^{103}$ Although periodic review of all cases undoubtedly would overburden the courts, ${ }^{164}$ perhaps it would be advisable to require periodic reports from agencies charged with responsibility for the youths during the continuance of juvenile court jurisdiction. ${ }^{165}$

\section{CONCLUSION}

The 1961 juvemile court law represents a significant attempt by the legislature to impose a uniform measure of orderliness on a judicial process which, otherwise; is committed to the informahty of the parens patriae philosophy. Some provisions of the new law may produce results that fall short of that measure of orderliness and uniformity intended by the legislature. In some instances, the provisions of the revised statute adequately express the intent of the legislature to meet a given problem, but certam omissions or ambiguous phrases may prevent full realization of that intent. In these cases, the appropriate remedy would seem to be immediate amendment of the statute. In other instances, the revised law suggests the possibility of many problems that may or may not arise in practice, depending upon the extent to which the practices of police departments, probation departinents, and juvemile courts have changed since 1961. In this connection, the authors empliasize that many of their conclusions have been based upon juvemile court practices antedating the revision. Consequently the present question is the extent to and the form in which problems will arise regarding current practice. It is therefore submitted that there is an immediate need for a survey of juvenile court practices since the enactment of the revised statute.

Joel Goldfarb

Paul M. Little

163 Juvenile court jurisdiction may be terminated upon the petition of the youth or a person having an interest in the child showing a change of circumstances or new evidence. CaI. WELFARE \& INST'NS CODE § 778. It would seem that reformation would constitute a "change of circumstance" within the meaning of the section.

164 An annual court review is provided for in cases involving dependent children under $\S 600$. CAL. WeLFARE \& INST'NS CODE $\S 729$.

185 CAT. WeLFARE \& INST'NS CODE $\$ 728$ now authorizes the court to require periodic reports concerning dependent children under $\$ 600$ from the agency responsible for the child. 